\title{
Party Identification and Level of Government: The Validity of Mixed Party Identifications
}

\author{
Patrick R. Cotter, University of Alabama \\ James Glen Stovall, University of Alabama
}

Previous research has found that some individuals give different answers when asked about their national, state and/or local party identifications. These response inconsistencies suggest that there is a level of government dimension to party identification. It is possible, however, that the consistency of individuals' responses to questions about their different party identifications is instead the product of measurement error. The validity of measures of mixed party identifications is investigated in this study. The results of the analysis support the conclusion that there is a level of government dimension to party identification.

\section{Introduction}

Party identification is a central concept in the study of public opinion and political behavior. As a consequence, researchers have devoted considerable effort to examining the origins and characteristics of individuals' party identifications. One line of this inquiry has been an investigation of whether party identification has a "level of government" dimension. That is, researchers have investigated whether individuals have different party identifications at different (i.e., national, state, or local) levels of government (Jennings and Niemi 1966; Converse 1966; Wright 1974; Perkins and Guynes 1976; Clarke et al. 1979; LeDuc and Clarke 1984; Hadley 1985; Maggiotto 1985; Niemi, Wright and Powell 1987; Clarke and Stewart 1987; Uslaner 1989, 1990; Martinez 1990 and Wekkin 1991).

Researchers have found that a number of citizens give different answers when asked about their national, state and/or local party identifications. The general explanation for these "mixed," "multiple," "dual," or "segmented" party identifications is that some individuals have different feelings about the parties or party systems at different levels of government. As a result, these individuals have different or mixed party identifications at different levels of government. In contrast, those who have similar or identical feelings about the parties or party systems at different levels of government have consistent party identifications. ${ }^{1}$

There are, of course, alternative explanations for why individuals give consistent or inconsistent answers to questions asking about their national, state and/or local party identification. Chief among these alternatives is measurement error. That is, a variety of measurement-related factors (i.e., the presence of "non- 
attitudes," interviewer mistakes, or coding or data entry errors) randomly may affect the consistency or inconsistency of individuals' responses to questions about their different party identifications. Additionally, some type of "need for consistency or inconsistency" systematically may affect individuals' responses to questions about their party identifications.

Obviously the existence of a level of government dimension is brought into question if measurement error, rather than variations in feelings about parties or party systems, is the source of the consistencies or inconsistencies in individuals' responses to questions about their party identifications. The relationships that previous researchers have found between mixed party identifications and other characteristics suggest that a level of government dimension to party identification does exist. ${ }^{2}$ Still, previous researchers have not considered thoroughly the possibility that measurement error accounts for the differences in individuals' responses to questions about their national, state and/or local party identifications. Consequently, the possibility remains that there is no level of government dimension to party identification.

The purpose of this study is to address the issue of whether there is a level of government dimension to party identification. Specifically, this study will investigate the validity of measures of mixed party identifications. While the immediate concern of the analysis is the quality of the existing measures of mixed party identifications, the more general question under study is whether or not there is a level of government dimension to party identification.

\section{Data}

The data used here to examine mixed party identifications are based on four surveys conducted in Alabama by Southern Opinion Research between 1989 and 1991. Each of the surveys is based on telephone interviews with random samples of adult Alabama citizens. In each case, a multi-stage method of random digit dialing was used to select the samples. The sample sizes range from 415 to 519.

In each of the Southern Opinion Research studies, respondents were asked separately about, first, their national party identification (i.e. "When it comes to national politics, do you consider yourself a Republican, a Democrat, an Independent, or what?) and second, their state party identification ("When it comes to state politics, do you consider yourself a Republican, a Democrat, an Independent or what?). The standard follow-up questions also were asked for both national and state party identification. Thus, each of the four surveys contains separate sevenpoint measures of respondents' national and state party identifications. ${ }^{3}$

Two measures of mixed party identification are studied here. The first measures the magnitude of the difference between individuals' national and state party identifications. The second measures the direction of the difference between individuals' national and state party identifications.

In constructing the magnitude measure, we will follow a procedure similar to that used in previous studies (for example, Clarke et al. 1976; Hadley 1985). 
Specifically, the magnitude of mixed party identification is determined by comparing the measure of national party identification. Based on this comparison, respondents are classified as consistent if they locate at the same point on the seven-point party identification scale (i.e., "strong Democrat" or "Republican leaning Independent" or "weak Republican") at both levels of government. Respondents are classified as partially consistent if their basic identifications (i.e., Democrat, Independent or Republican) are the same at both levels but either the intensity (i.e., weak or strong) or the direction (pure, Republican-leaning, or Democrat -leaning Independent) differ. All other respondents are classified as mixed identifiers. ${ }^{4}$

The direction of mixed party identification is measured by calculating the difference between an individual's national and state party identifications. These figures are then collapsed to place respondents into one of three categories: (1) those whose state party identification is in a more Democratic direction than their national identification, (2) those who have the same state and national party identifications, and (3) those whose state party identification is in a more Republican direction than their national identification. ${ }^{5}$

Figure 1 traces the number of consistent, partial and mixed party identifiers in Alabama during the 1989-1991 period. About one-in-six Alabamians are mixed identifiers. An additional 7 to 10 percent are partially consistent identifiers.

Figure 1 also contains information about the direction of mixed identifiers. Those who are not perfectly consistent generally tend to be more Democratic in state than in national party identification. On average, about 16 percent of the respondents are more Democratic at the state than at the national level. An average of about 9 percent are more Republican at the state level than at the national. For information about the characteristics of mixed identifiers, see Appendix A.

Figure 1

Mixed Party Identifications in Alabama 1989-1991

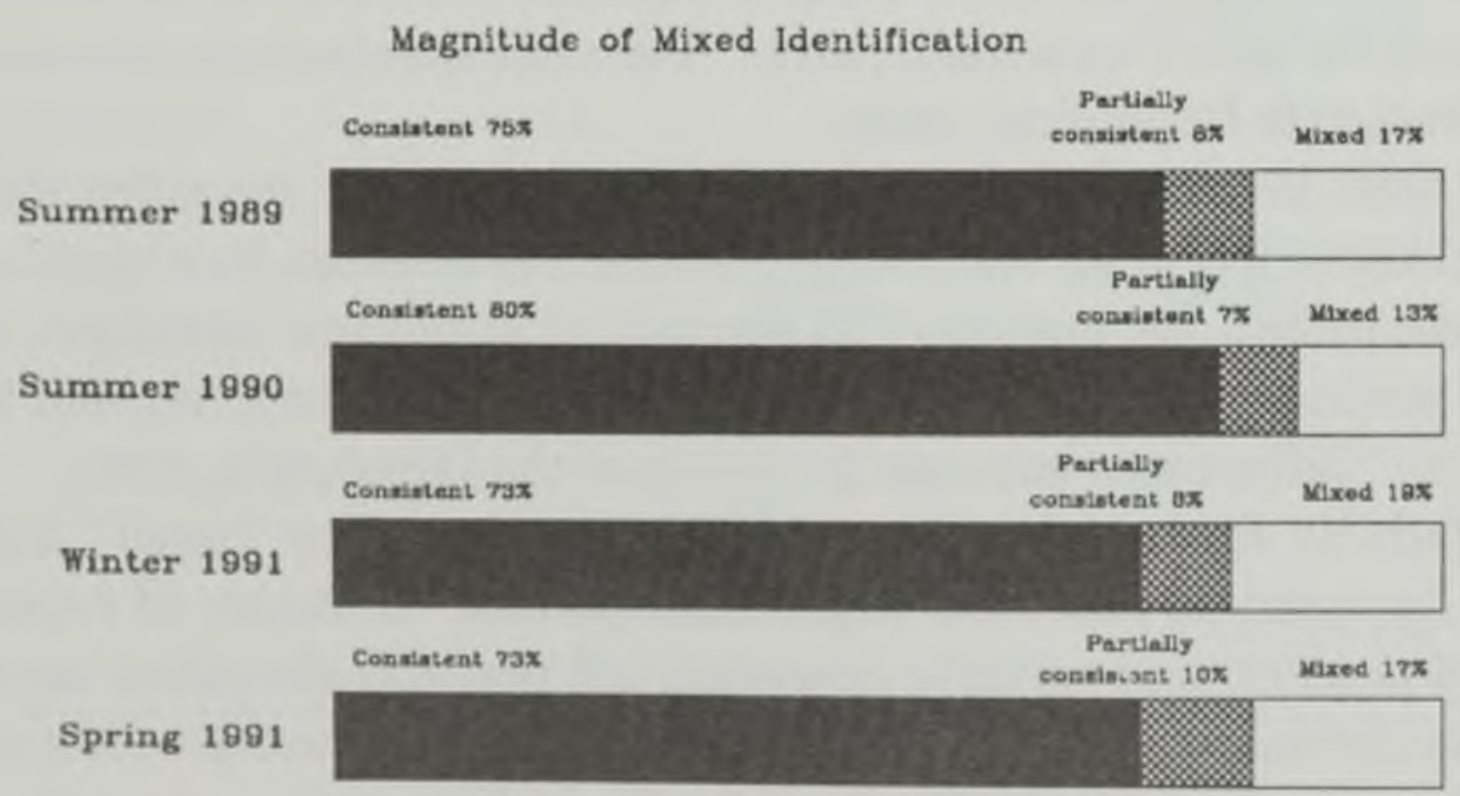


Direction of Mixed Identification

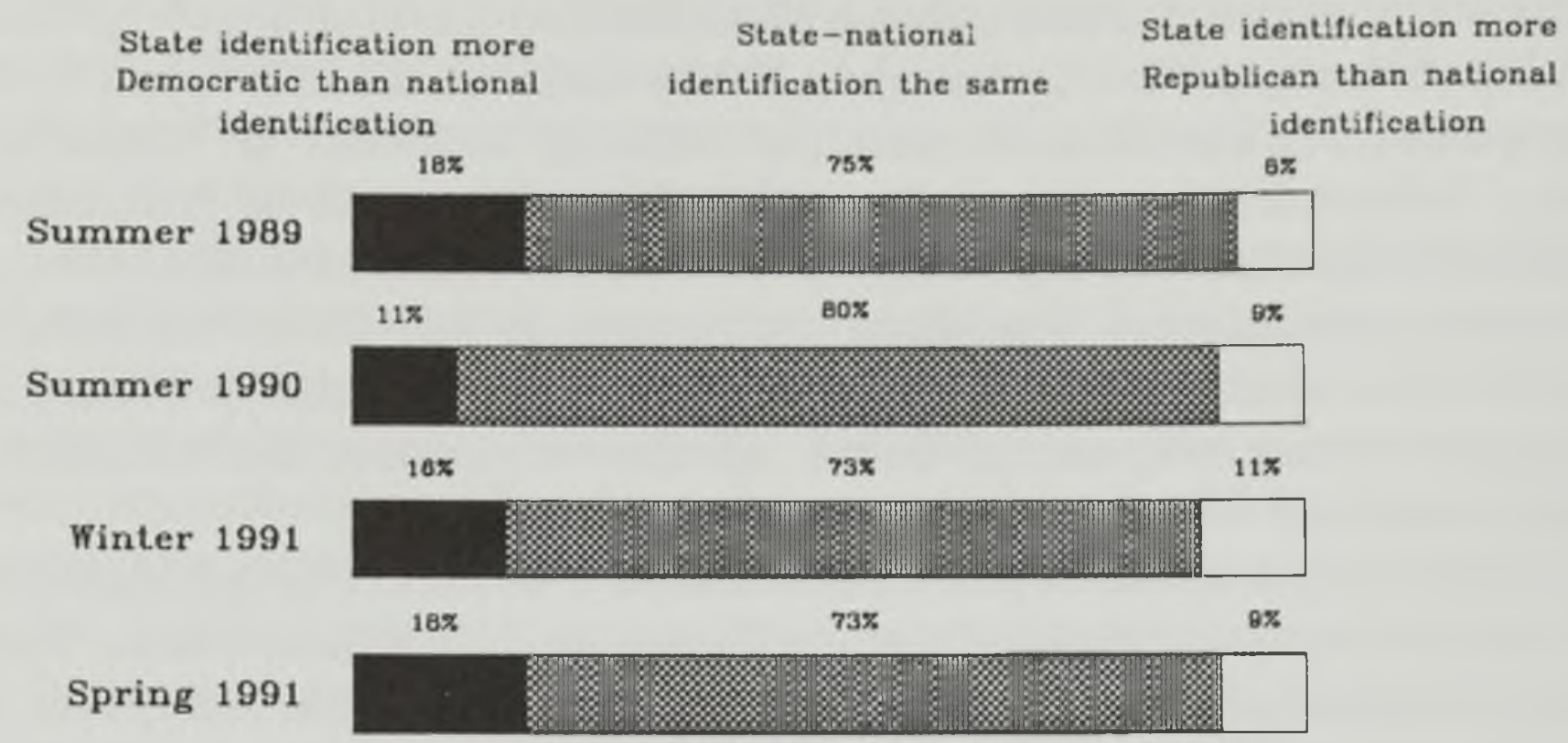

\section{Results: \\ Perceptions and Evaluations of Parties}

Mixed party identification presumably involves the way in which individuals perceive and evaluate the national and state levels of the two political parties. In general, mixed identifiers should be more likely than others to see differences between the state and national levels of a party. Similarly, mixed identifiers should be more likely than others to evaluate or rate the state and national levels of a party differently. Thus one way to test the validity of mixed party identifications is to examine the way in which mixed and consistent identifiers perceive and evaluate the national and state portions of the Democratic and Republican parties.

The available data permit several tests of the expected relationship between mixed identifications and perceived intra-party differences and evaluations. First, a question included in the Spring, 1991 study asked respondents whether "there are large differences, small differences or hardly any differences at all between the national and the state Democratic party." The same question was asked about the national and state Republican party.

As seen in Table 1, mixed and partial identifiers are more likely than consistent identifiers to say that there are differences between the national and state Democratic parties. A majority (53 percent) of consistent identifiers, but only about 40 percent of partially consistent or mixed identifiers, say that there are "hardly any" differences between the levels of the Democratic party.

Relatively few citizens say that there are "large" or "small" differences between the national and state Republican parties. Contrary to expectations, mixed ( 34 percent) and partially consistent (38 percent) identifiers are no more likely than consistent identifiers (30 percent) to say that there are either small or large differences between the levels of the Republican party.

A second test of the validity of mixed identifications employs questions, also

Table 1. Tests of 
Table 1. Tests of Validity of Mixed Party Identification-Perceived Differences and Consistency of Evaluations

Differences,

Different national-state

Democratic party

Consistent

$24.0 \%$

24.0

53.0

$100.0 \%$

319

$9.0 \%$
21.0
70.0
$100.0 \%$

318

$58.0 \%$
42.0
$100.0 \%$
337

$62.0 \%$

38.0

$100.0 \%$

337
Partially

consistent

$33.0 \%$

24.0

42.0

$100.0 \%$

45

$r=-.13 ; p<.01$
Mixed

$34.0 \%$

28.0

38.0

$100.0 \%$

79

Differences, national-state

Republican party

Large
Small
Hardly any
Total
$\mathrm{N}$

Rate national-state

Democratic party

Same
Differently
Total
$\mathrm{N}$

Rate national-state

Republican party

Same
Differently
Total
$\mathrm{N}$

72.0

$100.0 \%$

$37.0 \%$

63.0

$100.0 \%$

47

81

$\mathrm{r}=.22 ; \mathrm{p}<.001$

$$
r=.08 ; p=n . s
$$

$$
\mathrm{r}=.22 ; \mathrm{p}<.001
$$


included on the Spring, 1991 study, which asked respondents to rate the national Democratic party, the national Republican party, the state Democratic party, and the state Republican party on a one (negative) to ten (positive) scale. The absolute difference between a respondent's rating of the national Democratic and the state Democratic party then was calculated. Also calculated was the absolute difference between the ratings of the national and state Republican parties. These figures then were collapsed to show whether respondents gave the same or different ratings to the two levels of the Democratic or Republican parties.

The second half of Table 1 shows that, unexpectedly, mixed and partially consistent identifiers are not significantly more likely than consistent identifiers to rate the state and national segments of the Democratic party differently. About 58 percent of consistent identifiers rate the state and national Democratic party equally. Fewer (but not at a statistically significant level) partially consistent identifiers (45 percent) and mixed identifiers (48 percent) rate the two levels equally.

However, significant differences are found for the Republican party. About two-thirds (62 percent) of the consistent identifiers rate the national and state Republican parties the same. Substantially fewer mixed identifiers (37 percent) or partially consistent identifiers (28 percent) display the same pattern of responses. ${ }^{6}$

A third test of the validity of mixed party identification involves examining the consistency of the directional difference between an individual's national and state party identifications. In conducting this test we will rely on the directional, rather than the magnitude, measure of mixed party identifications.

The other measure used in this part of the analysis is based on calculating the arithmetic (rather than absolute) difference between individual's ratings of the national and state Democratic (Republican) parties. The result of this process was then collapsed into three categories: (a) those who rated the state party more favorably than the national party, (b) those who gave the same rating to the national and state party, and (c) those who rated the state party less favorably than the national party.

Again, those who have the same national and state party identifications should be more likely than others to rate the national and state units of a party equally. Additionally those with a more Democratic state than national party identification should be more likely than others to rate the state Democratic party more favorably than the national Democratic party. Conversely, those who have a more Republican state than national party identification should be more likely than others to rate the national Democratic party more favorably than the state Democratic party. The reverse pattern should exist in the ratings of the national and state Republican parties.

Table 2 shows that, as expected, those with the same national and state parties are more likely than others to rate the two segments of the Democratic party equally. Additionally, those with a more Democratic state than national party identification are more likely than others to rate the state Democratic party more 
favorably than the national party. About 39 percent of those with a more Democratic state than national party identification rate the state party more favorably than the national. In contrast, only 8 percent of those with a more Republican state than national party identification rate the state Democratic party more favorably than the national party. Additionally, those with a more Republican state than national party identification are the most likely to rate the national Democratic party more favorably than the state party. The national party is rated above the state party by 41 percent of those with a more Republican state than national party identification. Only 16 percent of those with a more Democratic state than national party identification rate the national Democratic party more positively than the state party.

Table 2. Test of Validity of Mixed Party Identifications:

Consistency of Evaluations

\begin{tabular}{|c|c|c|c|}
\hline $\begin{array}{l}\text { Rate national-state } \\
\text { Democratic } \\
\text { party }\end{array}$ & $\begin{array}{l}\text { State more Democratic } \\
\text { than national } \\
\text { identification }\end{array}$ & $\begin{array}{l}\text { State National } \\
\text { identification } \\
\text { the same }\end{array}$ & $\begin{array}{l}\text { State more Republican } \\
\text { than national } \\
\text { identification }\end{array}$ \\
\hline $\begin{array}{l}\text { State party rated } \\
\text { more favorably than } \\
\text { national }\end{array}$ & $39.0 \%$ & $21.0 \%$ & $8.0 \%$ \\
\hline $\begin{array}{l}\text { State-national } \\
\text { party rated the same }\end{array}$ & 45.0 & 58.0 & 51.0 \\
\hline $\begin{array}{l}\text { State party rated } \\
\text { less favorably than }\end{array}$ & & & \\
\hline national & 16.0 & 21.0 & 41.0 \\
\hline $\begin{array}{l}\text { Total } \\
N\end{array}$ & $\begin{array}{l}100.0 \% \\
89\end{array}$ & $\begin{array}{l}100.0 \% \\
337\end{array}$ & $\begin{array}{l}100.0 \% \\
39\end{array}$ \\
\hline $\begin{array}{l}\text { Rate national-state } \\
\text { Republican } \\
\text { party }\end{array}$ & & & \\
\hline $\begin{array}{l}\text { State party rated more } \\
\text { favorably than }\end{array}$ & & & \\
\hline national & $14.0 \%$ & $14.0 \%$ & $26.0 \%$ \\
\hline $\begin{array}{l}\text { State-national } \\
\text { party rated the }\end{array}$ & & & \\
\hline same & 33.0 & 62.0 & 36.0 \\
\hline $\begin{array}{l}\text { State party } \\
\text { rated less favorably }\end{array}$ & & & \\
\hline than national & 54.0 & 24.0 & 38.0 \\
\hline $\begin{array}{l}\text { Total } \\
\text { N }\end{array}$ & $\begin{array}{l}100.0 \% \\
89\end{array}$ & $\begin{array}{l}100.0 \% \\
337 \\
r=-.15 ; p=.001\end{array}$ & $\begin{array}{l}100.0 \% \\
39\end{array}$ \\
\hline
\end{tabular}


Even stronger results are found when evaluations of the national and state Republican parties are considered. Compared to inconsistent identifiers, those with the same national and state party identifications are almost twice as likely to rate the national and state Republican parties equally. Those with a more Democratic state than national identification are more likely than others to rate the state Republican party less favorably than the national party. Similarly, those with a more Republican state than national identification are more likely than others to give the state GOP a more favorable rating than the national Republican party.

Overall, while the findings contain some contradictions, the results of the analysis suggest that the measures of mixed party identifications are valid. Mixed identifiers are generally more likely than others to perceive differences between levels of a party, or to rate different levels of a party differently. Also, the direction of the inconsistencies in individuals' party identifications is related in the expected manner to the differences in evaluations of the state and national levels of a party.

\section{Political Preferences}

Examining the relationships existing between individuals' political preferences and their different party identifications is another way to test the validity of mixed party identifications. Specifically, if there is a level of government dimension to party identification, then individuals should use or not use their different party identifications in different circumstances. Individuals should use their national identification in reaching decisions regarding national politics and their state identification in reaching decisions regarding state politics. Conversely, individuals should not use their state party identification regarding national politics, or their national party identification in the realm of state politics.' Unfortunately, testing for the presence of these relationships or non-relationships is complicated by several factors.

Among these complicating factors are, first, a fairly frequent lack of certainty concerning what is the relevant level of politics. For example, it seems safe to say that national politics is the relevant arena when investigating attitudes about the president, and that state politics is the appropriate arena when discussing evaluations of the governor or the state legislature. The picture is hazier, however, when considering the many topics that cross federal boundaries such as Congressional elections or issues such as abortion or education.

Second, national and state party identification are closely related. In the four studies examined here the average correlation ( $r$ ) between national and state party identification is .88. This strong interrelationship makes it difficult to determine statistically the independent influence of state and national party identifications on individuals' attitudes or behaviors.

We will attempt to minimize these problems, first, by limiting our examination to topics which clearly involve either national or state politics, but not both. Second, we will make use of the direction of mixed party identification measure. The magnitude measure is not used because it groups all inconsistent identifiers 
together, regardless of the direction of the difference between their state and national identifications. As a result, the magnitude measure is not very helpful in studying how individuals use their different party identifications. In addition, the direction measure is relatively unrelated either to national or state party identification. ${ }^{8}$ Consequently, employing the directional measure makes it possible to avoid using both state and national identification in the same statistical analysis and therefore makes it possible to identify the separate influence of each on individuals' attitudes and behaviors.

From the viewpoint of national party identification, the direction measure indicates if an individual has the same, a more Democratic, or a more Republican state party identification. From the viewpoint of state party identification, the direction measure indicates if an individual has the same, a more Democratic, or a more Republican national party identification. Depending on the circumstance, then, the direction measure can indicate either an individual's national or state party identification. Thus, in some situations, the direction measure should be related significantly to a measure involving either state or national politics. In other situations, no significant relationship should exist between the direction measure and the national or state politics variable.

For example, imagine a regression analysis involving both national party identification and the direction measure as independent variables. Imagine also that the dependent variable in this analysis is an item clearly associated with national, but not state, politics. If there is a level of government component to party identification, then an individual's opinions on the national politics item should be guided by their national, but not their state, party identification. Thus in this case the national party identification measure should be related significantly to the dependent variable. However, the direction measure (which in this case indicates the supposedly irrelevant fact that an individual has a more Democratic or Republican state identification) should not be related significantly to the dependent variable.

Different results should occur if the same national politics dependent variable is used in a regression analysis that has state (rather than national) party identification and the direction measure as independent variables. In this case, state party identification should not be related to feelings about the national politics object. However, this non-relationship is unlikely to be found because of the high interrelationship between national and state party identifications. Still, national identification should have some influence over and above that captured by its relationship with state party identification. This extra influence should be reflected by the presence of a significant relationship between the direction measure (which, because of the presence of state party identification in the analysis, now indicates the individual's national identification) and the dependent variable.

Thus, the focus of the analysis conducted here is whether the direction measure is related or not related, in the expected manner, to items dealing with 
either national or state politics. The direction measures should be unrelated to a national politics dependent variable when national party identification is included in the analysis. However, the direction measure should be related significantly to the national politics dependent variable when state party identification is included in the analysis. Opposite results should occur when an object involving state politics is used as a dependent variable.

The specific national politics measures used in the analysis as dependent variables include (a) an item, included in two of the surveys, asking respondents to evaluate George Bush as president, (b) an item asking respondents (in a survey conducted shortly after the outbreak of hostilities) to rate Bush's performance in the conflict with Iraq, and (c) items asking respondents their opinions about five issues. ${ }^{9}$ The state politics measures used as dependent variables include an item that asked citizens to rate the performance of Republican Guy Hunt as governor. This item was included in all four of the surveys. Another item used here asked respondents if the state government should continue flying the Confederate flag over the capitol building. Finally, it is possible to examine the influence of mixed identifications in the arena of state electoral politics. Specifically, a Southern Opinion Research survey was conducted immediately prior to the November, 1990 general election. This survey is based on telephone interviews with a random sample of 772 registered voters. Included on this survey were two items that asked respondents to evaluate the competing gubernatorial candidates. A "comparative candidate evaluation" measure was calculated by subtracting the evaluation of the Republican candidate from the evaluation of the Democratic candidate (for the advantages of using this measure, rather than vote intention, see Page and Jones 1979). See Appendix B for the wording of the national and state politics items used to examine the validity of mixed party identifications.

Table 3 shows that, as expected, the directional measure is unrelated to evaluations of Bush when national party identification is included in the analysis. The directional measure, however, is significantly related to attitudes about Bush when state party identification is included in the analysis. Similar results are found on an item asking citizens to rate Bush's handling of the conflict with Iraq.

The expected results also occur on the issue items involving "fair treatment of blacks," "jobs and standard of living," and "economic position of blacks." Specifically, the directional measure is related significantly to opinion on these issues only when the state identification item is included in the analysis (Table 4). On the two remaining issue items ("economic position of women" and "fewer services"), the directional measure is unrelated to opinions both when state party identification or national party identification are included in the analysis. One possible reason for this is that the bivariate relationship between these two issue items and either measure of party identification is relatively weak.

As expected in the area of state politics, the directional measure is related significantly to evaluations of Hunt when national party identification is used in the analysis (Table 5). Also as predicted, the directional measure is not related to evaluation of Hunt when state party identification is included in the 
Table 3. Regression Analyses Examining Validity of Mixed Party Identification: Evaluation Measures Involving National Politics

\begin{tabular}{|c|c|c|c|c|c|c|}
\hline & \multicolumn{2}{|c|}{$\begin{array}{l}\text { Party } \\
\text { identification }\end{array}$} & \multicolumn{2}{|c|}{$\begin{array}{l}\text { Direction of } \\
\text { mixed party } \\
\text { identifications }\end{array}$} & \multirow{2}{*}{$\begin{array}{l}\text { Significance } \\
\text { direction } \\
\text { measure }\end{array}$} & \multirow[b]{2}{*}{$\mathrm{R}^{2}$} \\
\hline & & & & beta & & \\
\hline \multicolumn{7}{|c|}{$\begin{array}{l}\text { Rate Bush as President } \\
\text { (Summer, 1990) }\end{array}$} \\
\hline \multicolumn{7}{|l|}{ national party } \\
\hline identification & .19 & .48 & .01 & .00 & n.s. & .23 \\
\hline \multicolumn{7}{|l|}{ state party } \\
\hline identification & .19 & .45 & .34 & .19 & $<.001$ & .22 \\
\hline \multicolumn{7}{|c|}{$\begin{array}{l}\text { Rate Bush as President } \\
\text { (Spring, 1991) }\end{array}$} \\
\hline \multicolumn{7}{|l|}{ national party } \\
\hline identification & .15 & .38 & -.06 & -.04 & n.s. & 14 \\
\hline \multicolumn{7}{|l|}{ state party } \\
\hline identification & .15 & .36 & .20 & .13 & $<.01$ & .14 \\
\hline \multicolumn{7}{|c|}{$\begin{array}{l}\text { Rate Bush's handling } \\
\text { of conflict with Iraq }\end{array}$} \\
\hline \multicolumn{7}{|l|}{ national party } \\
\hline identification & .15 & .36 & .02 & .02 & n.s & .13 \\
\hline \multicolumn{7}{|l|}{ state party } \\
\hline identification & .14 & .34 & .27 & .16 & $<.001$ & .12 \\
\hline
\end{tabular}

analysis. Similarly, the expected pattern of relationship and non-relationship is found when opinions about the issue of whether the state government should fly the Confederate flag over the capitol building is examined (Table 6).

Finally, the directional measure is related significantly to comparative evaluations of the gubernatorial candidates when national identification is included in the analysis. Unexpectedly, it also is significantly related to evaluations when state party identification is used in the analysis. However, the regression coefficient for the directional measure is stronger when national rather than state identification is included in the analysis.

In summary, the results of the analysis provide support for the conclusion that there is a level of government dimension to party identification. When relationships between the direction measure and the examined dependent variables are predicted to exist, the results of the analysis show that, with few 
Table 4. Regression Analyses Examining Validity of Mixed Party Identification: Issue Measures Involving National Politics

\begin{tabular}{|c|c|c|c|c|c|c|}
\hline & $\begin{array}{l}\text { Party } \\
\text { identific } \\
\text { b }\end{array}$ & $\begin{array}{l}\text { ation } \\
\text { beta }\end{array}$ & $\begin{array}{l}\text { Directio } \\
\text { mixed } p \\
\text { identific } \\
\quad b\end{array}$ & $\begin{array}{l}\text { n of } \\
\text { arty } \\
\text { cation } \\
\text { beta }\end{array}$ & $\begin{array}{l}\text { Significance } \\
\text { direction } \\
\text { measure }\end{array}$ & $\mathrm{R}^{2}$ \\
\hline \multicolumn{7}{|c|}{$\begin{array}{l}\text { Fair treatment } \\
\text { in jobs for blacks }\end{array}$} \\
\hline $\begin{array}{l}\text { national party } \\
\text { identification }\end{array}$ & -.05 & -.19 & -.08 & -.07 & n.s. & .05 \\
\hline $\begin{array}{l}\text { state party } \\
\text { identification }\end{array}$ & -.04 & -.18 & -.15 & -.14 & $<.01$ & .05 \\
\hline $\begin{array}{l}\text { Jobs-standard } \\
\text { of living }\end{array}$ & & & & & & \\
\hline $\begin{array}{l}\text { national party } \\
\text { identification }\end{array}$ & -.08 & -.23 & -.04 & -.03 & n.s. & .06 \\
\hline $\begin{array}{l}\text { state party } \\
\text { identification }\end{array}$ & -.08 & -.23 & -.18 & -.13 & $<.01$ & .06 \\
\hline $\begin{array}{l}\text { Economic pos } \\
\text { of blacks }\end{array}$ & & & & & & \\
\hline $\begin{array}{l}\text { national party } \\
\text { identification }\end{array}$ & -.08 & -.21 & -.01 & -.01 & n.s & .05 \\
\hline $\begin{array}{l}\text { state party } \\
\text { identification }\end{array}$ & -.08 & -.23 & -.14 & -.10 & $<.05$ & .05 \\
\hline $\begin{array}{l}\text { Economic pos } \\
\text { of women }\end{array}$ & & & & & & \\
\hline $\begin{array}{l}\text { national party } \\
\text { identification }\end{array}$ & -.05 & -.17 & -.01 & -.01 & n.s. & .03 \\
\hline $\begin{array}{l}\text { state party } \\
\text { identification }\end{array}$ & -.05 & -.16 & -.10 & -.08 & n.s. & .03 \\
\hline $\begin{array}{l}\text { Provide fewer } \\
\text { services }\end{array}$ & & & & & & \\
\hline $\begin{array}{l}\text { national party } \\
\text { identification }\end{array}$ & .04 & .12 & .00 & .00 & n.s. & .01 \\
\hline $\begin{array}{l}\text { state party } \\
\text { identification }\end{array}$ & .04 & .12 & .07 & .05 & n.s. & .02 \\
\hline
\end{tabular}


exceptions, these relationships do occur. Similarly, when no relationship is predicted, the results show that, with a single exceptions, the direction measure is unrelated to the dependent variable. In this exception, the relationship involving the difference measure is weaker than the equivalent one predicted to exist.

Table 5. Regression Analyses ExaminingValidity of Mixed Party Identifications: Evaluation Measures Involving State Politics

\begin{tabular}{cccc}
\hline & \multicolumn{2}{c}{ Direction of } & \\
Party & mixed party & Significance \\
Identification & identification & direction \\
b beta & b beta & scores & $\mathrm{R}^{2}$ \\
\hline
\end{tabular}

Rate Hunt as governor

(Summer, 1989)

national party

identification

$.11 \quad .32$

$-.19-.08$

$<.05$

state party

identification

$.11 \quad 30$

$.01 \quad .01$

n.s.

Rate Hunt as governor

(Summer, 1990)

national party

identification

$.17 \quad .42$

$\begin{array}{ll}-.22 & -.12\end{array}$

$<.05$

state party

identification

$.17 \quad .41$

$.08 \quad .04$

n.s.

Rate Hunt as governor

(Winter, 1991)

national party

identification

$-.18-.11$

$<.01$

state party

identification

$.14 \quad .34$

$.05 \quad .03$

n.s.

Rate Hunt as governor (Spring, 1991)

national party

identification

$.12 \quad .29$

$\begin{array}{ll}-.28 & -.17\end{array}$

$<.001$

.08

state party

identification

$.11 \quad .26$

$-.08 \quad-.05$

n.s.

.07 


\section{Summary and Conclusion}

This study investigated whether there is a level of government dimension to party identification. This was done by testing the validity of measures of mixed party identification. Specifically investigated were individuals' perceptions and evaluations of the Democratic and Republican parties. Also examined was the way individuals use their state and national party identifications. Overall, the results of the analysis support the conclusion that the measures are valid. Thus it is reasonable to conclude that there is a level of government dimension to party identification.

Given the probable existence of a level of government dimension, more information is needed concerning the number of mixed identifiers. More state and national level information is needed about the number and characteristics of mixed

Table 6. Regression Analyses Examining Validity of Mixed Identification:

Voting and Issues Measures Invol ving State Politics

\begin{tabular}{|c|c|c|c|c|c|c|}
\hline & $\begin{array}{l}\text { Panty } \\
\text { identif } \\
\text { b }\end{array}$ & $\begin{array}{l}\text { ication } \\
\text { beta }\end{array}$ & $\begin{array}{c}\text { Directi } \\
\text { mixed } \\
\text { identifi } \\
\mathrm{b}\end{array}$ & $\begin{array}{l}\text { of of } \\
\text { party } \\
\text { cation } \\
\text { beta }\end{array}$ & $\begin{array}{l}\text { Significance } \\
\text { direction } \\
\text { scores }\end{array}$ & $\mathrm{R}^{2}$ \\
\hline \multicolumn{7}{|c|}{$\begin{array}{l}\text { Fly Confederate flag } \\
\text { over Capitol }\end{array}$} \\
\hline $\begin{array}{l}\text { national party } \\
\text { identification }\end{array}$ & .05 & .23 & -.11 & -.12 & $<.05$ & .05 \\
\hline $\begin{array}{l}\text { state party } \\
\text { identification }\end{array}$ & .05 & .22 & -.03 & -.03 & n.s. & .05 \\
\hline $\begin{array}{l}\text { Comparative } \\
1990 \text { guberna } \\
\text { candidates }\end{array}$ & & & & & & \\
\hline $\begin{array}{l}\text { national party } \\
\text { identification }\end{array}$ & -.47 & -.63 & .52 & .18 & $<.001$ & .36 \\
\hline $\begin{array}{l}\text { state party } \\
\text { identification }\end{array}$ & -.46 & -.60 & -.29 & -.10 & .001 & .36 \\
\hline
\end{tabular}

identifiers. More information also is needed about the sources of mixed party identifications. Are such identifiers stable or unstable? Are such identifications the product of policy considerations, reactions to specific party leaders, or some other factors?

Finally, more information is needed about when individuals use their 
different party identifications. This requires a better understanding of the contents and determinants of what individuals perceive as involving national politics, state politics and local politics.

\section{NOTES}

'What specific factors may lead to mixed party identification is in dispute. For discussions of the traditional and revisionist views of party identification see, for example, Franklin 1984 and Green and Palmquist 1990.

${ }^{2}$ For example, in the United States researchers have found that mixed party identification is related to the strength and direction (Niemi, Wright and Powell 1987; Hadley 1985) of an individual's party identification. Additionally, mixed identifications are related to an individual's level of political activity (Niemi, Wright and Powell 1987; Hadley 1985), issue opinions (Hadley 1985), party loyalty, and likelihood of engaging in crossover voting (Hadley 1985; Wekkin 1991).

${ }^{3}$ Respondents were not asked about local party identifications. Thus this segment of mixed party identifications is not studied here.

${ }^{4}$ Responses with missing data values on either measure of party identification were deleted from the analysis. The magnitude measure used here differs from that employed by Clarke et al. (1979) in that Independents are not treated either as non-identifiers or single level identifiers.

A persistent issue in studying party identification is how, if at all, to combine the different categories of the measure (Keith et al. 1985; Wekkin 1988; Miller 1991). This debate centers on the questions of (a) whether "weak" and "strong" identifiers should be combined into a single category, and (b) whether "leaning" Independents should be treated as a separate category, as partisans, or as Independents.

In this study, we have chosen to maintain the seven-point party identification measure. We have done this for several reasons. First, it is not clear that the findings of previous research apply to this study since the concerm here is not differences between the party identifications of different individuals, but instead differences between an individual's state and national party identifications. Thus, previous research which shows that differences between categories are or are not important may not apply in studying mixed party identifications (for a related view, see Niemi, Wright, and Powell 1987). Second, even if the previous research does apply, the inconsistent recommendations of these studies do not clearly identify a preferred alternative to the seven-point measure. Finally, analyses using alternative ways of combining categories of the party identification measure produce results roughly similar to those reported here. In this study, twenty separate tests of the validity of mixed party identification are conducted. Using the seven-point party identification measure produces the expected result in 16 of these tests. When a five-point measure (formed by combining "weak" and "strong" identifiers) is used, the expected results also are found in 16 of the tests. A three-point party identification measure formed by combining "leaning" Independents with partisans (which has the effect of eliminating the partially consistent category) produces, using the same analysis techniques, expected results in ten of the tests. A three-point party identification measure, formed by combining all Independents into a single group (which again has the effect of eliminating the partially consistent category), produces the expected results in twelve of the twenty tests. Thus, while using either of the three-point measures does have some affect on the findings of the 
study, conclusions about the existence of a level of government component to party identification remain largely unchanged. Results of the analyses using the alternative measure of party identification are available from the authors.

${ }^{5}$ These categories alternatively can be described as (1) those whose national identification is in a more Republican direction than their state identification, (2) those who have the same national and state identifications, and (3) those whose national identification is more Democratic than their state identification. Obviously those in the second category (i.e. those with the same national and state identifications) are the same respondents who are in the consistent category on the magnitude measure.

${ }^{6}$ The fact that inconsistent identifiers rate the national and state Republican parties differently, but are not particularly likely to say that there are differences between the levels of the GOP, is puzzling. Perhaps the item directly asking about intra-party differences is more closely connected to a respondent's policy views. If this is the case, then the results suggest that mixed identification stems more from affective feelings about the different parties than from perceived intra-party policy differences.

${ }^{7}$ Determining whether the influence running between party identification and opinions or behavior is unidirectional or reciprocal again is beyond the scope of this study (Franklin, 1984; Green and Palmquist 1990).

${ }^{8}$ The average correlation ( $r$ ) between the direction measure and national party identification is .30 . For state party identification the average correlation is -..11.

${ }^{9}$ The issue items selected for analysis met two requirements: (a) they were significantly related to party identification, and (b) the wording of the items explicitly referred to "the government in Washington."

\section{APPENDIX A \\ Characteristics of Mixed Party Identifiers}

Strong party identifiers are more likely to have consistent state and national identifications than are weak identifiers (Figure 2). Also "pure" Independents are more consistent in their party identifications than are "leaning" Independents.

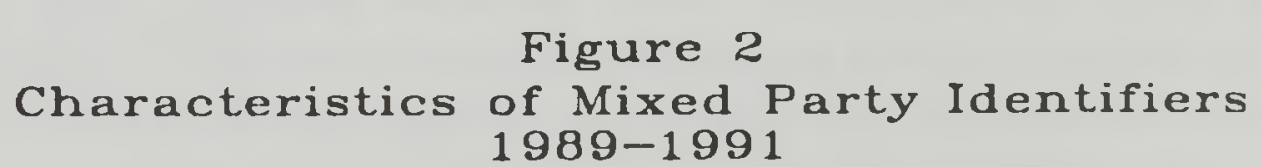

Magnitude of Mixed Identification

RACE

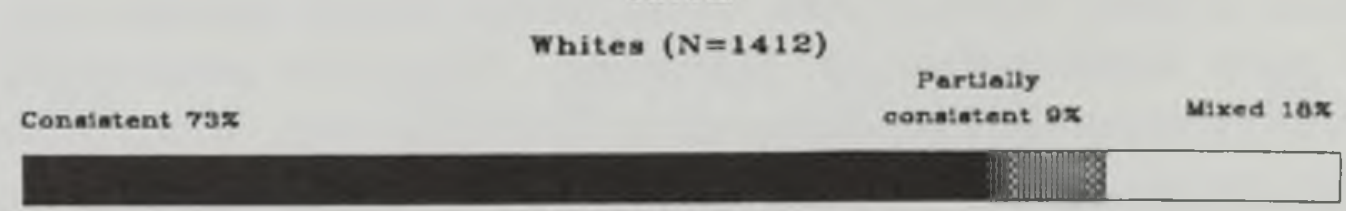

EDUCATION*

High sehool or less $(N=706)$ Partially

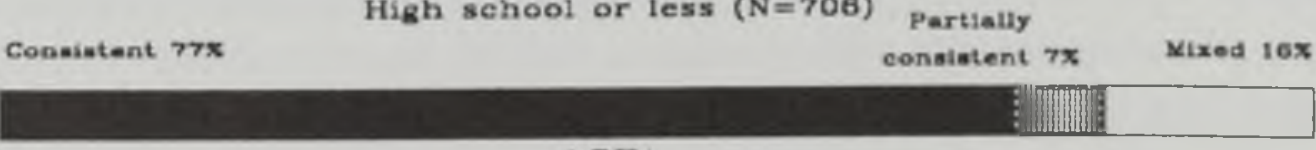

AGE*

45 years or younger $(\mathrm{N}-708)$ Pertially

Conwiatent $72 x$

consiotent $8 x$

Mixed $10 x$ 


$\begin{array}{ll}\text { Blacks }(N \cdot 336) & \text { Partially } \\ \text { Consistent } 81 \% & \text { consistent } 5 \pi \text { Vized } 14 \pi\end{array}$

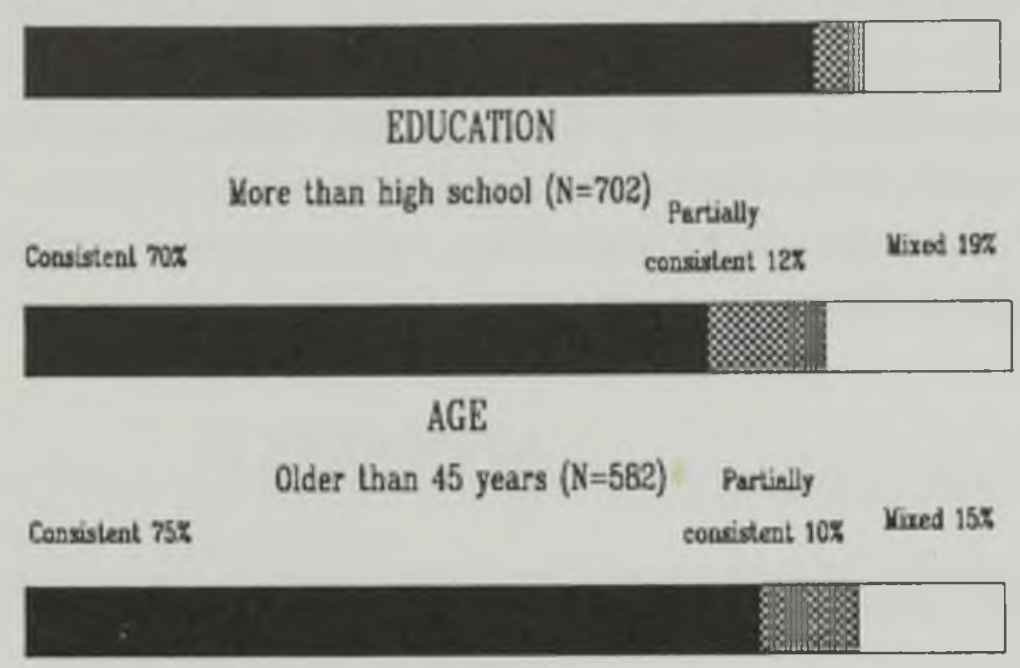

'hites only

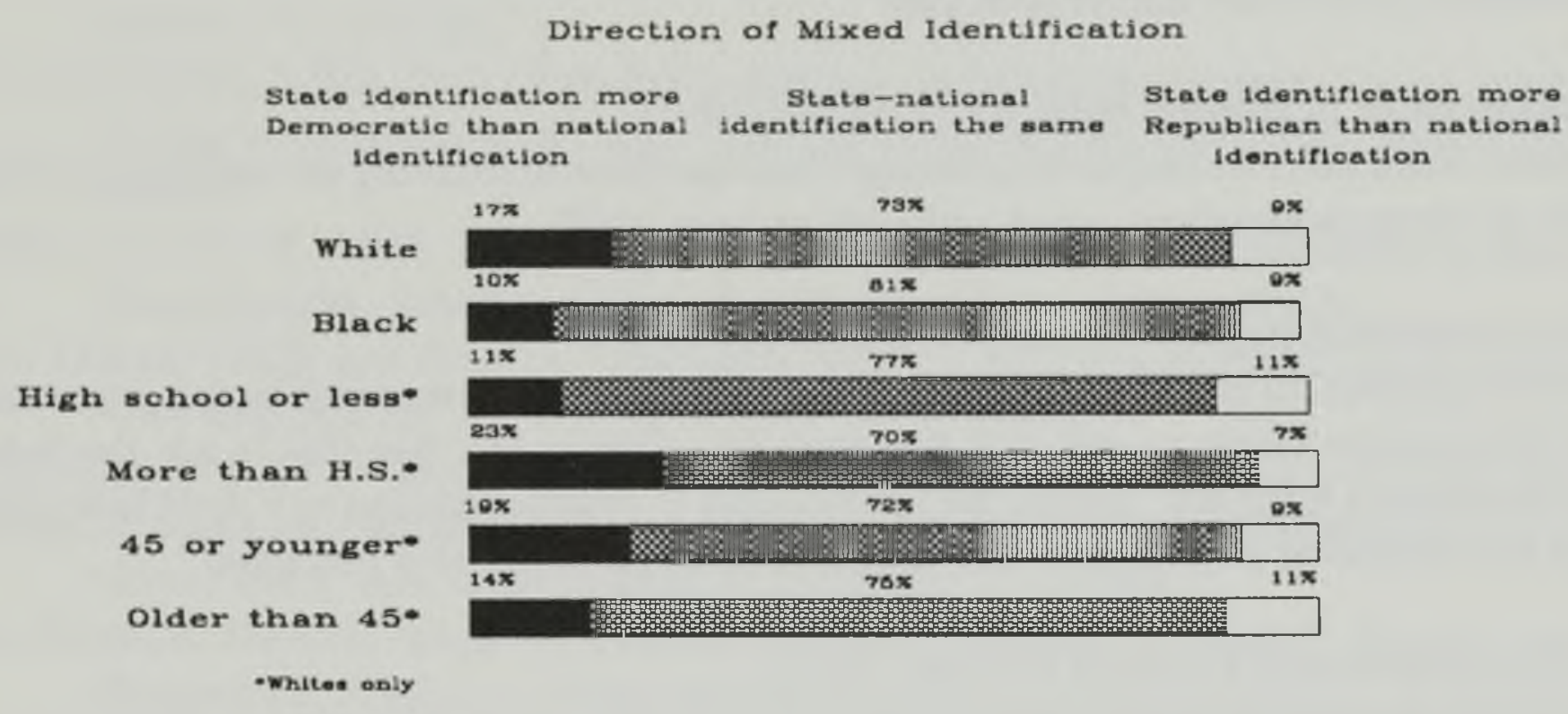

The results presented in Figure 2 also show that, while many citizens are mixed identifiers, the amount of difference between these individuals' national and state party identifications is relatively modest. Specifically, most mixed identifications stem from individuals identifying at one level with a party and at the other level as an Independent. Conversely, few individuals are mixed identifiers because they identify with one party at the national level and the opposing party at the state level.

Combining the results of the four Southem Opinion Research surveys shows that, in terms of the magnitude measure, there are some racial differences with regard to mixed party identifications (Figure 2). Black citizens are more likely than white citizens to have consistent state and national party identifications. Among white Alabamians, consistency in state and national party identifications is somewhat higher among less educated citizens. However, the number of mixed identifiers is about the same among less educated and more educated citizens. Little difference in consistency of party identifications is found between younger and older white Alabamians. Older citizens are operationalized as those 45 years of age or older, roughly dividing the public into pre- and post-1964 generations, in reflection of the Goldwater election's importance as a milepost in Southern politics 
(Stanley 1988).

In terms of the direction measure, whites tend to be more Democratic in their state than national party identifications. Among blacks, however, the number of more Democratic and more Republican identifiers are about equal. Similarly, among less educated citizens, the discrepancies between national and state identifications benefit the GOP and the Democratic party about equally. Among more educated citizens, relatively few citizens have a more Republican state than national party identification. Younger citizens also tend to be more Democratic at the state than national level, while among older citizens the partisan balance is about the same at the national and state levels.

\section{APPENDIX B}

Wording of national and state politics items used in regression analyses:

Rating of Bush (Summer, 1990; Spring, 1991)

"How would you rate the job that George Bush is doing as president? Is he doing an excellent, good, only fair or poor job?"

Rating Bush in conflict with Iraq (Winter, 1991)

"How would you rate the job that George Bush has done in handling the conflict with Iraq? Has he done an excellent, good, only fair or poor job?"

Fair treatment in jobs for blacks (Summer, 1990)

"Some people feel that if black people are not getting fair treatment in jobs, the government in Washington ought to see to it that they do. Others feel that this is not the federal government's business. Should the government in Washing ton see to it that black people get fair treatment in jobs or is this not the federal government's business?"

\section{Job and standard of living (Winter, 1991)}

"The government in Washington should see to it that every person has a job and a good standard of living." (strongly agree, agree, disagree or strongly disagree)

Improve position of blacks (Winter, 1991)

"The government in Washington should make every effort to improve the social and economic position of blacks and other minorities." (strongly agree, agree, disagree or strongly disagree)

Improve position of women (Winter, 1991)

"The government in Washington should make every effort to improve the social and economic situation for women." (strongly agree, agree, disagree or strongly disagree)

Provide fewer services (Winter, 1991)

"The government in Washington should provide fewer services, even in areas such as health and education, in order to reduce government spending." (strongly agree, agree, disagree or strongly disagree)

Rate Hunt (Summer, 1989; Summer, 1990; Winter, Spring, 1991)

"How would you rate the job Guy Hunt is doing as governor -- excellent, good, only fair or poor?" 
Fly Confederate flag (Summer, 1990)

"Do you favor or oppose the state of Alabama flying the Confederate flag over the state capitol building?"

Candidate evaluation (1990 pre-election survey)

"Do you generally feel positive, neutral, or negative about each of the following people?" (Paul Hubbert, Guy Hunt)

\section{REFERENCES}

Campbell, Angus, Philip E. Converse, Warren E. Miller and Donald E. Stokes. 1960. The American Voter. New York: Wiley.

Clarke, Harold D., Jane Jenson, Lawrence LeDuc and Jon H. Pammett. 1979. Political Choice in Canada. Toronto: McGraw-Hill.

Clarke, Harold D. and Marianne C. Stewart. 1987. Partisan Inconsistency and Partisan Change in Federal States: The Case of Canada. American Journal of Political Science 31: 383-407.

Converse, Philip E. 1966. On the Possibility of Major Political Realignment in the South. In Angus Campbell et al., eds., Elections and the Political Order. New York: Wiley.

Franklin, Charles H. 1984. Issue Preference, Socialization and the Evolution of Party Identification. American Journal of Political Science 28: 459-478.

Green, Donald Philip and Bradley Palmquist. 1990. Of Artifacts and Partisan Stability. American Journal of Political Science 34: 872-902.

Hadley, Charles D. 1985. Dual Partisanship in the South. Journal of Politics 47: 254-268.

Jennings, M. Kent and Richard G. Niemi. 1966. Party Identification at Multiple Levels of Government. American Journal of Sociology 72: 86-101.

Keith, Bruce, E., DavidB. Magleby, Candice J.Nelson, Elizabeth Orr, Mark C. Westlye and Raymond E. Wolfinger. 1986. The Partisan Affinities of Independent 'Leaners.' British Journal of Political Science 16: 154-184.

LeDuc, Lawrence and Harold D. Clarke. 1984. Partisan Instability in Canada: Evidence From a New Panel Study. American Political Science Review 78: 470-484.

Maggiotto, Michael A. 1985. The Locus of Partisanship:A Federal Analogy. Presented at the 1985 Southern Political Science Association Meeting, Nashville, Tennessee.

Martinez, Michael D. 1990. Partisan Reinforcement in Context and Cognition: Canadian Federal Partisanship, 1974-79. American Journal of Political Science 34: 822845.

Miller, Warren, E. 1991. Party Identification, Realignment and Party Voting: Back to Basics. American Political Science Review 85: 557-568.

Niemi, Richard G., Stephen Wright and Lynda W. Powell. 1987. Multiple Party Identifiers and the Measurement of Party Identification. Journal of Politics 49: 1093-1103.

Page, Benjamin I. and Calvin C. Jones. 1979. Reciprocal Effects of Policy Preferences, Party Loyalties and the Vote. American Political Science Review 73: 10711090.

Perkins, Jerry and Randall Guynes. 1976. Partisanship in National and State Politics. Public Opinion Quarterly 40: 376-378. 
Stanley, Harold W. 1988. Southern Partisan Changes: Dealignment, Realignment or Both? Journal of Politics 50: 64-85.

Uslaner, Eric M. 1989. Multiple Party Identifiers in Canada: Participation and Affect. Journal of Politics 51: 993-1003.

. 1990. Splitting Image: Partisan Affiliations in Canada's 'Two Political Worlds.' American Journal of Political Science 34: 961-981.

Wekkin, Gary D. 1991. Why Crossover Voters Are Not 'Mischievous Voters:' The Segmented Partisanship Hypothesis. American Politics Quarterly 19: 229-247. 1988. The Conceptualization and Measurement of Crossover Voting. Western Political Quarterly 41: 105-114.

Wright, Gerald C., Jr. 1974. Electoral Choice in America: Image, Party and Incumbency in State and National Elections. Chapel Hill: Institute for Research in Social Science. 